\title{
Clear Cell Hidradenoma
}

National Cancer Institute

\section{Source}

National Cancer Institute. Clear Cell Hidradenoma. NCI Thesaurus. Code C7567.

An uncommon benign neoplasm of the sweat glands characterized by the presence of clear cells. 